トピックス

\title{
めまいと酸塩基平衡
}

\author{
中村 節子
}

\section{Vertigo and acid-base balance}

\author{
Setsuko Morinaka-Nakamura \\ Department of Otorhinolaryngology, Kobe Japanpost Hospital
}

内耳における酸塩基平衡の報告は多いが, 血液 ガス・酸塩基平衡とめまいに関する報告は少な い。本稿では酸塩基平衡とめまいに関する過去の 報告および私見を述べる。

\section{酸塩基平衡障害とめまいに関する動物実験}

1）血液ガス・酸塩基平衡異常とめまい

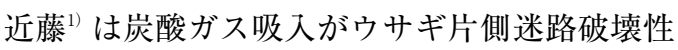
眼振に影響するのを報告した。しかしながら破壊 性眼振代償後の実験はしていない。

Morinaka $^{2)}$ はウサギの片側迷路破壊性眼振代償 後に代謝性アシドーシス（塩化アンモニウム静 注）や呼吸性アシドーシス（ $\mathrm{CO}_{2}$ 吸入）により眼 振が再出現するのを報告した。再実験でも同様 で, 生理食塩水静注や正常コントロールでは眼振 出現はなかった。以上より呼吸性や代謝性アシド ーシスは代償状態の片側迷路破壊後ウサギにめま いを再発させ, 前庭代償破綻によりめまい再発作 を引き起こすことが示唆された。

2) 内耳に扔ける酸塩基平衡

内リンパ囊の内リンパは酸性（pH 6.6-7）であ る3)。内リンパ嚢には炭酸脱水素酵素 ${ }^{4) 5}, \mathrm{vH}^{+}-$ ATPase $^{3 / 6)}$, Pendrin $^{377)}$, CAII $^{3)}$, いくつかの Aqp ${ }^{910)}$, $\mathrm{V}(2)-\mathrm{R}^{10)}, \mathrm{NKCC} 1,2^{10)}$ が発現している。酸性 であることは内リンパ囊の機能に重要であると考 えられており ${ }^{3)}$ ，上記に述べたことは内リンパの 酸塩基平衡や水代謝に関与すると考えられてい る。また pendrin の変異は甲状腺異常や内リンパ

神戸聥信病院耳鼻咽喉科
酸性化を起こし，甲状腺腫，両前庭機能低下によ る反復性めまい発作や平衡障害, 進行性または変 動性の両側高度感音性難聴の症状を呈する Pendred 症候群を起こすとされる ${ }^{112)}$ 。ついでながら Aqp 3 はメニエール病において血液中 DNA の変 異が多いことが報告されている ${ }^{13)}$ 。今後, 解析や 治療への応用が進むものと期待される。

\section{血液ガス・酸塩基平衡異常とめまいに関する臨 床的報告}

Celestino らは代謝性アシドーシスのメニエー

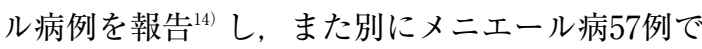
代謝性アルカローシスは39例, 代謝性アシドーシ スは 4 例と報告した ${ }^{15)}$ 。牧本 ${ }^{16)}$ はメニエール病 10 例中 6 例で代謝性アシドーシス傾向, 3 例は完全 な代謝性アシドーシスとし, 高橋ら ${ }^{17)}$ はにメニエ ール病 3 例はめまい発作時に代謝性アシドーシス を呈し,うち 2 例は呼吸性アシドーシス合併と報 告した。

Morinaka ${ }^{18)}$ はめまい患者121例の動脈血ガス 分析を報告した。めまい期には $50.4 \%$ に異常があ り, その $93.4 \%$ は $\mathrm{HCO}_{3}^{-}$増加（代謝性アルカロ ーシス）で最も多く, 8 例は $\mathrm{PaCO}_{2}$ 上昇, うち 1 例は $\mathrm{pH}$ 低下を伴った。 $\mathrm{HCO}_{3}^{-}$上昇の原因疾患 は少なく, $\mathrm{HCO}_{3}^{-}$増加原因は呼吸性アシドーシス による代償と考えた。

緩解期にも血液ガス分析を 22 例に行い，12例に 軽度血液ガス異常が残存，10例は正常だった。緩 解期後のめまい再発は血液ガス異常群に有意に多 く, 緩解期の血液ガス異常群にめまい再発率が高 
いことを示した。

以上よりめまい患者の約半数に血液ガス異常が あり, 血液ガス異常は前庭代償の破綻を起してめ まい頻度が多くなることが示唆された。また血液 ガス異常はメニエール病より中枢末梢前庭疾患に 有意に多く, 中枢性呼吸機能障害や中枢前庭障害 で前庭代償破綻を起こしやすい可能性が示唆され た。

また Morinaka ら ${ }^{19)}$ は2004年にめまい患者112 名にチンパノメトリーを施行, 中耳圧左右差はメ ニエール病のめまいや再発に有意に関連し，めま い時の血液ガス異常とも関連することを示した。 特にメニエール病では血液ガス異常は中耳圧の $50 \mathrm{daPa}$ 以上の左右差と関連していた。異常中耳 圧は必ずしも患側に作用するのではなく，中耳圧 左右差が前庭系に影響を及ぼす要因の 1 つになる のではと示唆し, 中耳圧左右差は血液ガス異常と 共にめまいのリスクを高めることを示唆した。ま た中耳圧左右差は頸性めまいや椎骨脳底動脈循環 不全とも関連していた。最近では Park ら ${ }^{20)}$ はチ ンパノメトリー用の携帯用装置で中耳圧を長時間 反復測定し,メニエール病では突発性難聴や正常 者に比べて有意に低い中耳圧（平均一 $43 \mathrm{daPa}$ ) を示したと報告した。病期による差，患側と健側 との差, 反復測定の間隔による差, 血液ガスとの 関連等の報告が待たれる。

Ozkui ら ${ }^{21)}$ は2007年に58例のめまい患者の 2 例 でアシドーシス，15例にアルカローシスを認め, 治療により正常化したことを報告した。24例に $\mathrm{HCO}_{3}^{-}$の上昇または低下を認め, $\mathrm{HCO}_{3}^{-}$上昇の 3 例はめまいの経過と一致していた。血液ガスの異 常はめまい発作と関連することを示唆し, これま での報告に合致している。

Hinoki $^{22)}$ や山田 ${ }^{23)}$ は脊柱側弯症によるめまいを 報告した。側弯症や胸椎の前弯は, 胸郭変形によ り肺のスペースは狭小化し, 呼吸器症状や慢性呼 吸性アシドーシスを起こすことが知られてい る。 ${ }^{24)}$ 酸塩基平衡異常との関連も今後の検討課題 の 1 つと思われる。

今後, 内耳酸塩基平衡と血液ガス・酸塩基平衡 との関連についても解析が進むものと期待され る。

\section{文献}

1 ）近藤楠吉：炭酸瓦斯中毒ノ前庭性眼球運動二
及ボス影響二就テ.耳鼻臨床 $23: 126$ 135,1929

2 ) Morinaka S: Effect of experimental acidosis on nystagmus in rabbits. Acta Otolaryngol 114: 130-134, 1994

3 ) Dou H, Xu J, Wang Z, et al.: Co-expression of pendrin, vacuolar $\mathrm{H}^{+}$-ATPase alpha 4-subunit and carbonic anhydrase II in epithelial cells of the murine endolymphatic sac. J Histochem Cytochem 52: 1377-1384, 2004

4 ) Yamashita H, Bagger-Sjöbäck D, Sekitani T: Expression of carbonic anhydrase isoenzymes in the developing endolymphatic sac of the human fetus and the mouse embryo. J Laryngol Otol 106: 98-102, 1992

5 ) Tsujikawa S, Yamashita T, Tomoda K, et al.: Effects of acetazolamide on acid-base balance in the endolymphatic sac of the guinea pig. Acta Otolaryngol Suppl 500: 50-53, 1993

6 ) Stanković KM, Brown D, Alper SL, et al.: Localization of $\mathrm{pH}$ regulating proteins $\mathrm{H}^{+} \mathrm{AT}-$ Pase and $\mathrm{Cl}^{-} / \mathrm{HCO}^{-}$exchanger in the guinea pig inner ear. Hear Res 114: 21-34, 1997

7 ) Everett LA, Morsli H, Wu DK, et al.: Expression pattern of the mouse ortholog of the Pendred's syndrome gene $(P d s)$ suggests a key role for pendrin in the inner ear. Proc Natl Acad Sci USA 96: 9727-9732, 1999

8 ) Fukushima M, Kitahara T, Uno Y, et al.: Effects of intra tympanic injection of steroids on changes in rat inner ear aquaporin expression. Acta Otolaryngol 122: 600-606, 2002

9 ) Taguchi D, Takeda T, Kakigi A, et al.: Expression and immunolocalization of aquaporin6 (Aqp 6) in the rat inner ear. Acta Otolaryngol 128: 832-840, 2008

10) Nishimura M, Kakigi A, Takeda S, et al.: Expression of aquaporins, vasopressin type 2 receptor, and $\mathrm{Na}^{+}-\mathrm{K}^{+}-\mathrm{Cl}^{-}$cotransporters in the rat endolymphatic sac. Acta Orolaryngol 129: 812-818, 2009

11) Royaux IE, Belyantseva IA, Wu T, et al.: Localization and functional studies of pendrin in 
the mouse inner ear provide insight about the etiology of deafness in Pendred syndrome. J Assoc Res Otolaryngol 4: 394-404, 2003

12) Kim HM, Wangemann P: Epithelial cell stretching and luminal acidification lead to a retarded development of stria vascularis and deafness in mice lacking pendrin. PLoS One 6: 1-12, 2011

13) Candreia C, Schmuziger N, Gurtler N: Molecular analysis of aquaporin genes 1 to 4 in patients with Meniere's disease. Cell Physiol Biochem 26: 787-792, 2010

14) Celestino D, Iannetti G: Meniere's disease and plasmatic hyperosmolarity. J Laryngol Otol 87: 229-234, 1973

15) Celestino D, Cerulli N, Iannetti G, et al.: Acidbase equilibrium in Meniere's disease. J Laryngol Otol 90: 263-275, 1976

16）牧本一男：メニエール病薬物療法における血 清電解質測定並びに血液ガス分析. 切替一 郎, 後藤修二編. 耳鼻咽喉科診療二頁の秘 訣. 156-157頁, 金原出版, 東京, 1977

17）高橋三郎, 野田三洋子, 伊藤敬子, 他 : メ二 エル病症例の眩暈発作に伴う代謝と平衡機能
の観察．岐阜市民病年報 $2 ：$ 49-60, 1982

18) Morinaka S, Nakamura H: Arterial blood gas abnormalities in patients with dizziness. Ann Otol Rhinol Laryngol 107: 6-9, 1998

19) Morinaka S, Nakamura H: Middle ear pressure in patients with dizziness. Ann Otol Rhinol Laryngol 113: 906-913, 2004

20) Park JJ, Luecke K, Luedeke I, et al.: Longterm middle ear pressure measurements in inner ear disorders. Acta Otolaryngol 132: 266-270, 2011

21) Ozkul KC, Arslan DI: Arterial blood gas abnormalities during attacks of dizziness. Kulak Burun Bogaz Ihtis Derg 17: 143-147, 2007

22) Hinoki M: Scoliosis and body equilibrium $-\mathrm{A}$ neurotogical approach-. In Vertigo viewed from neurotology, pp 284-304, Kanehara \& Co., Ltd.; Tokyo, 2003

23）山田憲吾 : 脊柱側弯症と平衡機能. 耳鼻臨床 69増 $3 ： 1224-1235,1976$

24) Driscoll P, Brown T, Gwinnutt C, et al.: A simple guide to blood gas analysis. 片山正夫 監訳. シンプルガイド血液ガス. 58-81 頁, 医学書院, 東京, 2009 